\title{
Value Chain Actors, Farm-gate Price and Farmer Loyalty in Strategic Vertical Coordination in the Maize Out-Grower Farming in Sri Lanka
}

\author{
K. K. A. Kiriveldeniya ${ }^{1}$ and H. S. R. Rosairo ${ }^{1 *}$
}

Date Received: 23 ${ }^{\text {rd }}$ October 2019 / Date Accepted: $18^{\text {th }}$ February 2020

\begin{abstract}
Purpose: Maize is a popular field-crop in Sri Lankan agriculture and it is a key ingredient of animal feed. Its cultivation under out-grower farming arrangements is considered to be a win-win strategy for farmers and agribusiness firms to overcome the limitations in farming and marketing of the commodity and to use the farmer loyalty over competitive price offers. The purpose of the study was to explore the key players in the maize value chain and to assess the relationship between the buying price and the out-grower farmer loyalty towards their out-grower firm.
\end{abstract}

Research Method: The study was conducted in Monaragala and Anuradhapura; major maize farming districts in Sri Lanka. Primary data was collected from intermediaries: collectors and, stockists, and ordinary farmers and out-grower farmers using interviewer administered structured questionnaires. Value chain analysis, Farmer Loyalty Index and Spearman's rank correlation tests were adapted in analysis of the maize value chain, assessment of out-grower farmer loyalty and to check the relationship between the buying price and out-grower farmer supply of produce to out-grower firm respectively.

Findings : Input and service providers, ordinary and out-grower farmers, collectors, stockists, feed millers, retailers and poultry farmers were the key players in the maize value chain. Farmers sold their harvest mainly in two forms as wet and dry. Restricted control over the buying (farmgate) price has increased the side-sales of out-grower farmers with middlemen. This has caused a 45 percent of negative deviation from the targeted supply of out-grower firms from their out-grower farmers. According to the out-grower farmer loyalty assessment, which was based on their opinion, majority (67 percent) of them claimed to be loyal towards their out-grower firm. Therefore, out-grower farming seemed to be a good strategy for the out-grower firms. However, in actual fact, only 33 percent of out-grower farmers have supplied the whole harvest to their out-grower firm. Their significant response in selling towards the highest available market price had concluded that the maize out-grower farming as a practically less effective strategy to continue for an assured supply of maize for out-grower firms.

Research Limitations : The study was conducted with the limitations of time and facilities to approach a sample which was spread-out in the two districts.

Originality / Value : The study showed that out-grower farming was an ineffective strategy in maize cultivation as the farmers have higher consideration on available higher market prices than the price offered by their out-grower firms. Policy implications are required to legally enforce the out-grower contracts, formation and adaptation of national level price formula for maize procurement and supportive insurance scheme to address crop failures to positively support the out-grower farming in maize production under outgrowing and enhance the national production.

Keywords: agricultural production, out-grower farming, maize value chain, farmer loyalty, pricing

\section{INTRODUCTION}

Nature of the world agriculture industry is becoming industrialized with biological and information technologies; economic growth; mechanization; increasing scale of organization
${ }^{I^{*}}$ Department of Agribusiness Management, Faculty of Agricultural Sciences, Sabaragamuwa University of Sri Lanka, BelihulOya, Sri Lanka. 70140

rosairo@agri.sab.ac.lk

그은 http://orcid.org/0000-0002-9092-6186 
and the modernization of production; and processing and distribution systems (Boehlje and Doering, 2000). Developing countries seem to have aligned their development strategies with the structural changes in the world agriculture industry (Kirsten and Sartorius, 2002). Production is also changing from an industry dominated by family-based and small-scale farms or firms to larger firms, that coordinate across the production and distribution value chain to address the market failures (Boehlje and Doering, 2000: Grosh, 1994) and increased integrations of world market (Reardon and Barrett, 2000). This industrialization of agriculture industry has a greater requirement of higher level of managed coordination as vertical integrations across the commodity chains, so these vertical integrations could elevate efficiency and minimize transaction costs (Kirsten and Sartorius, 2002). As a result of these changes, agriculture shows its transition from open market production to vertically coordinated agri-businesses with the purpose of producing a greater range of high-quality differentiated products (Esham, et al., 2005: Esham, and Usami, 2005: Sofranko et al., 2000). Different forms of vertical coordination(and alliances) have become a dominant feature of agricultural supply chains. However, the coordination tends to be higher in differentiated agricultural products that are relatively labour intensive (Kirsten and Sartorius, 2002). The vertical coordination of agribusinesses firms in commodity value chains combines diverse commercial enterprises with heterogeneous combination of factors of production including input supply, farm production (throughput) and the output (marketing) sector, to meet consumer demands (Rosairo and Potts, 2016).

The importance of agricultural sector in the economic development in developing countries such as Sri Lanka was identified as, it is the livelihood of a significant portion of their rural community (Senanayake, 2004). Maize, the second largest cereal cultivation in Sri Lanka, is exceptionally popular in Anuradhapura and Monaragala districts which are responsible for approximately two-thirds of the national production (Department of Agriculture Sri Lanka (DOASL), 2018). Out of 7.34 per cent of agricultural contribution for national Gross Domestic Production (GDP), 0.14 per cent comes from cereals (except rice) (Central Bank of Sri Lanka (CBSL), 2014-2018). Seventy-five per cent of higher demand for maize prominently comes from provender industry (DOASL, 2001), especially for the poultry industry because they have become regular food items in Sri Lankan menus during the period of 2003 to 2012 (Department of Animal Production and Health (DAP\&H), 2016). However, limitations in expansion of local maize faming; poor technological expertise, marketing facilities and fair prices (Champika and Abeywickrama, 2014) had led to import 63 per cent of national requirement of maize for the production of animal feed. Therefore, effective planning in national maize cultivation becomes essential to limit the imports and to become nationally selfsufficient from maize production.

Out grower(OG) farming is a form of vertical coordination of agribusiness firms in food value chains. An OG firm can be defined as a firm maintaining a business relationship with a group of OG farmers who supply a semi-finished or a finished commodity to the firm that supplies a range of inputs and facilities including extension services, quality checking and pricing of harvest, assured market for the produce with transport facilities for its OG farmers. Under the theory of Transaction Cost Economics (TCE), agribusiness firms focus in reducing the risks regard to production, and possession of land and labor (Herath and Weersink, 2009) through the OG farming arrangements. This has been a successful income-generating avenue for risk aversive small-holders in developing countries (Karunagoda et al., 2010: Goodwin and Schroeder, 1994). In this way, OG farming has become an important institution for empowering poor small-scale farmers in developing countries and to provide access towards more profitable markets (Kirsten and Sartorius, 2002) while reducing public expenditure on credit programs, price supports, input subsidies and government research and extension programs (Karunagoda et al., 2010: Key and Runsten, 1999). Out-grower farming supports farmers by providing new technology, assured markets and secured inputs, prices and their production 
as collateral (Esham, et al., 2006: Kirsten and Sartorius, 2002: Eaton and Shepherd, 2001) for their self-sustained development (Weatherspoon et al., 2001) to overcome the most of uncertainties described by Smale et al., (1994) in his study of land allocation in high yielding varieties adoption models. Most of these OG farming programs were composite arrangements involving private firms, the government, non-governmental organizations, parastatal bodies and international aid or lending agencies, (Glover, 1984). The firms and governments anticipate that $\mathrm{OG}$ farming has a potential of improving incentives, increasing income for farmers and positive multiplier effects for deprived rural economies (Barrett et al., 2012: Bellemare, 2010: Bijman, 2008: Reardon et al., 2009: Singh, 2002: Grosh, 1994). However, OG farming in developing countries has experienced mixed results, gaining some successes; improved farmer's income (Barrett et al., 2012: Bellemare, 2012: Warning and Key, 2002) and many failures (Barrett et al., 2012:Oya, 2012:Prowse, 2012:Singh, 2002:Key and Runsten, 1999) as they could be a result of high default rate, biased terms, delayed payments, cheating, and lack of compensation for crop failure (Guo et al., 2005: Singh, 2002) followed by Barrett et al., (2012) reporting cases of high participation turnover due to lack of commitment to honor agreements by either party. It was mainly criticized as a weak legal institution that does not guarantee the contract enforcement, existing chances of opportunistic behaviour of growers which created a high-risk element to the OG firm.

Out-grower farming facilitates the strengthening of agricultural supply chain and the reduction in marketing costs and stabilization of prices (Karunagoda et al., 2010). Under the OG farming, buyer directly involved in the management of supply chain as well as the value chain from farm level to the end user level. As the buyer firm has an assured market, it vertically coordinates at every link within the supply chain (Champika and Abeywickrama, 2014). Their promotion of large-scale maize production requires the consideration of both financial profitability and technical feasibility, there by interlinking the domestic production and to increase local supply while reducing the imports (Natesan and Jogaratnam, 1997). Popularization of the OG operation in maize is a result of the development of maize-based feed industry and feed processors being encouraged to rely more on local suppliers in Sri Lanka.

Value-adding food supply chains are involved in the movement of products from production to consumption while gaining an incremental value at the marketplace (Stevenson and Pirog, 2008; Kaplinsky and Morris, 2000). Analysis of the organization and behavior of the participants in the value chain enables the diagnosis of the constraints (Guo et al., 2005: Singh, 2002), identification of necessary action to enhance the performance of the value chain and to contribute towards the national policy (Kirimi, et al., 2011).

Agribusiness firms in Sri Lanka engage in their vertical coordination in food commodity chains (Esham, et al., 2005: Esham, and Usami, 2005) under OG operations. It was implemented through farmer loyalty to gain an assured supply at the end of the season. This built up farmer loyalty through OG farming made them to be deeply committed to re-enter into preferred product/ service constantly over time, regardless of the situational influences for switching behavior (Oliver 1999). The study area of supplier (farmer) loyalty towards buyer (firm) has received a poor attention. To assess this type of loyalty Boniface, et. al.,(2010), had proposed the mirror reflection of the meaning of customer loyalty to explain the loyalty of suppliers to their buyers. Ramsay and Wagner (2009) have emphasized that converting the emphasis from buyer requirements to suppliers will improve the joint trading performance with reduced conflicts in buyer-seller interactions.

Behavioral, composite and attitudinal loyalty are three facets of supplier loyalty observed in supplier-buyer relationship in OG operations in agri-business. Behavioral loyalty (Jacoby and Chestnut, 1978) results the repetitive supply by individual farmers for same buyer and attend in constant word-of-mouth promotion (Andreassen and Lindestad, 1998; Bettencourt and Brown, 1997; Zeithaml et al., 1996). Continuous supply 
for same buyer and recommending the buyer to others (Rauyruen and Miller, 2007; Chaudhuri and Holbrook 2001) reflect their composite loyalty (Rauyruen and Miller, 2007). The behavioral and attitudinal loyalty (Bennett and Rundle-Thiele, 2002) of farmers in business to business (B2B) environments ensures longterm relationships with the exchange partner (Rauyruen and Miller, 2007) and enhanced sustainability of future business environment (Chumpitaz and Paparoidamis, 2007). This paper outlines supplier loyalty of maize OG farmers as the motivation to continuously supply their harvest and to be engaged in a longterm relationship with the OG firm. This also envisages that the supplier loyalty is necessary to develop OG farmers' behavioral attitudes toward the OG firm to recommend the OG firm to others and to do repetitive business with the firm. The profitability in business transactions however, has a considerable effect on supplier loyalty (Reichheld, 1993). Therefore, processors and other buyers considered to work more closely with supplier farmers to build a strong relationship as a strategy to reduce supplier switching behavior for a continuous and constant supply (Rauyruen and Miller, 2007) and as a long-term investment. Quantitative measure of loyalty is been an under studied area but vital area to be studied when it comes to measuring of success of OG. Therefore, the study has developed the Farmer Loyalty Index (FLI) to assess the out-grower farmer loyalty towards their OG firm.

Farmer loyalty and commitment act as a social capital in OG operations which claimed to be their most valuable asset (Nilsson et al., 2012). Continuous supply, lower transaction costs, enhanced efficiency and reduced post-harvest losses were identified as beneficial effects for agribusiness firms by managing a loyal supplier group for themselves (Batt, 2003). The factors that affect the uncertainty will lead to breach of loyalty towards their OG firms. Loyalty on the other hand, has no direct monetary benefits but could be expected in the longer term as an outcome of cooperative system (Fulton and Vlark, 1996). Farmers tend to exit when it is cheaper than their existence or availability of outside options such as higher prices (Morfi, et al., 2014: Bogetoft and Olesen, 2002). This paper intends to report the findings of a study on (a) the engagements at the upper stream of maize value chain (MVC) and the role of OG firm and (b) assessing the effectiveness of adapting OG farming as a strategy to enhance the farmer loyalty and to gain long term profits for both sides besides competitive price offers. The findings regarding the engagements at the upper stream of MVC would provide the focus on how to increase the efficiency of supply of maize along the MVC and identify the facts: the OG farmer preferences during the harvesting season and the effect of their disloyal reactions, that required to be addressed during the designing of OG farming arrangements for a successful implementation.

\section{MATERIALS AND METHODS}

\section{Empirical framework:}

Farmer loyalty is expected to be a result of satisfaction (Tsay, et al., 2014; De Wulf et al., 2001); healthy relationship between the supplier farmer and OG firm (Boniface, 2010; Prahinski and Benton, 2004; Batt, 2003); and the trust (Sartorious and Kirsten, 2002; Batt and Rexha, 2000; Gow et al., 2000) that were built due to their engagement in OG farming. The long-term success of OG farming was partly a result of developed farmer loyalty and their long-term loyal commitment (Fornell et al., 1996). Price satisfaction (Batt, 2003: Hueth and Ligon, 1999), input quality (Natesan and Jogaratnam, 1997: Athaide et al., 1996) and, education and training (Athaide et al., 1996) have a direct impact on supplier loyalty and the business relationship. Reasonable and fair price offered by the OG firm, positively influence the level of farmer's trust (Gyau and Spiller, 2007) and also the relationship. Correct alignment of these factors within the $\mathrm{OG}$ mechanism especially at the designing stage is anticipated to be a must for its effectiveness (Abebe, et al., 2013). The current study assess the maize OG farmer loyalty towards their OG firm based on the FLI which is developed with three variables and five sub-variables for each. 
The value chain analysis helps to identify the activities that are most valuable, the activities which need to improve and the activities need to minimize in order to provide competitive advantages. Primarily there are three main types of value chain activities such as; (1) noncost incurred non-value adding (NCINVA) activities; (2) cost incurred non-value adding (CINVA) activities; and (3) value-adding (VA) activities (Karim and Biswas, 2016; Hines and Rich, 1997). A customer is willing to pay only for the VA activities. Therefore, analysis itself helps to reduce the repetition or to eliminate the NCINVA activities, to do the necessary changes to eliminate the CINVA activities and to continue the involvement of value adding activities (Karim and Biswas, 2016). The ultimate objective of value chain analysis is to create a shared vision among chain participants with regard to challenges and opportunities; promotion of coordinated linkages among producers, processors and retailers; and improvement of an individual firm's competitive position in the market place.

\section{Research method}

Research location: The study was conducted in the Anuradhapura district of North Central province and in the Monaragala district in the Uva province. According to agro-ecological classification, these two districts are classified as low country dry zone (DL1). Historically, these districts belonged to the maize belt where over two thirds of the total national production took place (DOASL, 2018). Intervention of private sector is high in maize farming in these districts due to their high contribution towards the national production. Therefore, agri-business firms, OG farmers and ordinary farmers, collectors, stockists, feed millers, and service providers in MVC are prominent in Monaragala and Anuradhapura districts and the MVC are unique within the area.

Sampling technique: Thirty intermediaries; collectors and stockists, and thirty ordinary maize farmers in MVC were selected through purposive sampling technique. Sixty-seven OG farmers were selected from the two districts using the multi-stage cluster sampling technique. In addition, officials from the DOASL, feed millers and poultry farmers were selected as key informants.

Data collection and analysis: Primary data on key value chain players and their activities were gathered through an interviewer administered structured questionnaire. Data included were the farming/ business operations, technology usage, the main value adding activities, noncost incurring non-value adding activities and cost incurring non-value adding activities. Outgrower farmer loyalty towards the OG firm was assessed through a FLI that included the three variables; satisfaction, healthy business relationship and trust. Each variable included five indicators (Table 01) measured through five-point Likert scale (5- Highly agreed to 1Least agreed). The reliability of the FLI index was measured with Cronbach alpha.

$$
\text { Farmer Loyalty Index }(F L I)=\sum_{i=1}^{k} \frac{A_{i}}{\mathrm{kP}_{i}}
$$

$\mathrm{A}_{\mathrm{i}}=$ Actual score of $i^{\text {th }}$ dimension

$\mathrm{P}_{\mathrm{i}}=$ Potential score of $i^{\text {th }}$ dimensions

$\mathrm{k}=$ Number of dimensions applicable $(\mathrm{k}=3)$

The value for FLI may range from 0 to 1 . Outgrower farmers were also classified according to their actual loyalty. Spearman's rank correlation coefficient test was used to determine whether the farmers' decision to sell their harvest to the OG firm (loyalty) depends on the price that the OG firm pays to them. Secondary data such as cost of production details, national maize production, extents of cultivation, poultry production, and per capita consumption were obtained from the OG firms, DOASL and DAP\&H. 
Table 01: Variables of Farmer Loyalty Index.

\begin{tabular}{|c|c|}
\hline Variable name ( $i^{\text {th }}$ dimension) & Indicators \\
\hline $\begin{array}{l}\text { Satisfaction } \\
\text { The OG farmer satisfaction can be obtained by } \\
\text { providing a better service of providing them the } \\
\text { necessary farming inputs, services, knowledge when it } \\
\text { is required and a better income. }\end{array}$ & $\begin{array}{l}\text { High quality inputs provided on time } \\
\text { Good service provided during procurement } \\
\text { Assured buyback } \\
\text { Buying price } \\
\text { Income after loan and sales charges deduction }\end{array}$ \\
\hline $\begin{array}{l}\text { Healthy relationship } \\
\text { (built through the immediate contact point - } \\
\text { Agricultural Extension Officer AEO) } \\
\text { The service of AEO officers is crucial factor to develop } \\
\text { a health relationship with OG farmers as they are the } \\
\text { immediate linkage OG farmers have with the OG firm. }\end{array}$ & $\begin{array}{l}\text { Ability to contact AEO any time } \\
\text { AEO available on call } \\
\text { OG firm accountable on tasks and } \\
\text { responsibilities } \\
\text { Providing instant solutions for farming issues } \\
\text { High service quality during buy back } \\
\text { operations }\end{array}$ \\
\hline $\begin{array}{l}\text { Trust } \\
\text { Trust of OG farmers towards the OG firm can be } \\
\text { developed by giving them a better-quality service and a } \\
\text { better price for the produce. }\end{array}$ & $\begin{array}{l}\text { High quality of inputs and services } \\
\text { Increased quantity and quality of produce } \\
\text { High quality of extension service } \\
\text { Better service during buy back operations } \\
\text { Income after price deductions }\end{array}$ \\
\hline
\end{tabular}

\section{RESULTS AND DISCUSSION}

\section{Maize value chain within the key maize growing areas in Sri Lanka}

Value chain participants and their activities were mapped subsequent to the study. The key participants were characterized as farmers, processors, traders, and consumers. Processors included stockists, feed millers, poultry farmers and OG firms. The collectors, wholesale and retail traders who are also players in the MVC do not add value. Various activities of the MVC participants were identified as; supply of inputs and services for production, production/ farming, primary processing and bulking, secondary processing and packaging, sales and distribution, and consumption (Figure 01).

\section{Supply of Inputs and Services for Production:} The necessary conditions of production included land, labour, inputs, finance, machinery renting and transport services. Inputs and services were mainly provided by input suppliers and service providers. Almost all the OG farmers (98 per cent) had their own land for cultivation and 68 per cent of them were large scale land holders (above 5 acres). Forty-seven percent of them utilized the whole land only for maize cultivation due to higher returns of investment and lesser management practices compared to paddy cultivation.

Three types of labour were utilized in maize farming; mainly family labour (average of 2 members per farmer), and shared labour (average of 3 persons per farmer per season), to reduce the labour cost in production. Insufficiency in those two types resulted hiring required manpower. On average, the utilization of hired labour was 12 units per acre per season at a daily wage of $1,000.00 \mathrm{LKR}$.

Main three material inputs included seeds, fertilizer and agrochemicals for crop-protection. Farmers, OG and ordinary farmers, obtained credit facilities to purchase these inputs in the first instance. This credit later was followed with machinery renting, hired labour and household expenses. Some farmers were dependent on local money lenders at the end of the season by using their harvest as collateral. This behavior was observed with both groups of farmers. Outgrower farmers who opt to obtain credit from local money lenders had to sell their entire or part of the harvest to lenders at rates set by them. This has placed both the OG farmers and their OG firms at a great disadvantage. Commercialized hybrid maize cultivation had increased the maize yields from 1500 to 3500 
kg per ac per season (hybrid seed requirement to cultivate one acre of maize was five kilos at 6,050.00 LKR in total) along with the fertilizer application (average cost was 14,050.00 LKR per acre in total). During the Maha season of 2018, farmers had experienced a significant yield reduction (1100kg per ac) due to low precipitation during the time of application of fertilizer. Mechanization has been a prominent feature in maize farming. The average cost of renting disc plough and furrower with the tractor for land preparation and huller machine (locally known as the Tsunami machine) was observed to be $12,000.00 \mathrm{LKR}$ per season.

Personal savings; borrowings from relatives and friends; village level (local) money lenders (mainly stockists and collectors); mortgages of household effects; agricultural loans from banks; and the government assistance programs were their available sources of financial and material credit. The OG farmers were supported by the OG firm to approach formal bank loans of up to 30, 000.00 LKR per acre per season.
These loans were settled from their income from harvesting. Batt (2000), also reported such arrangements in potato farming in Asia where the seed suppliers have adopted a long-term coordination towards securing regular supplies of seed potatoes and they have considered making long-term investments to win and retain the potato farmer's business.

Services and service providers: Agricultural extension and insurance are the major services approached the farmers during cultivation. It was estimated that some OG firms spent around 35 million LKR per season to maintain their extension staff who is mainly involved in OG farmer credit programs from commercial banks and transfer of technical knowhow. This was approximately $1.00 \mathrm{LKR}$ per kilo of the volume collected per season by the OG firm. Five thousand and three hundred LKR of crop insurance per acre was allocated as an insurance premium which was eventually paid by the farmer.

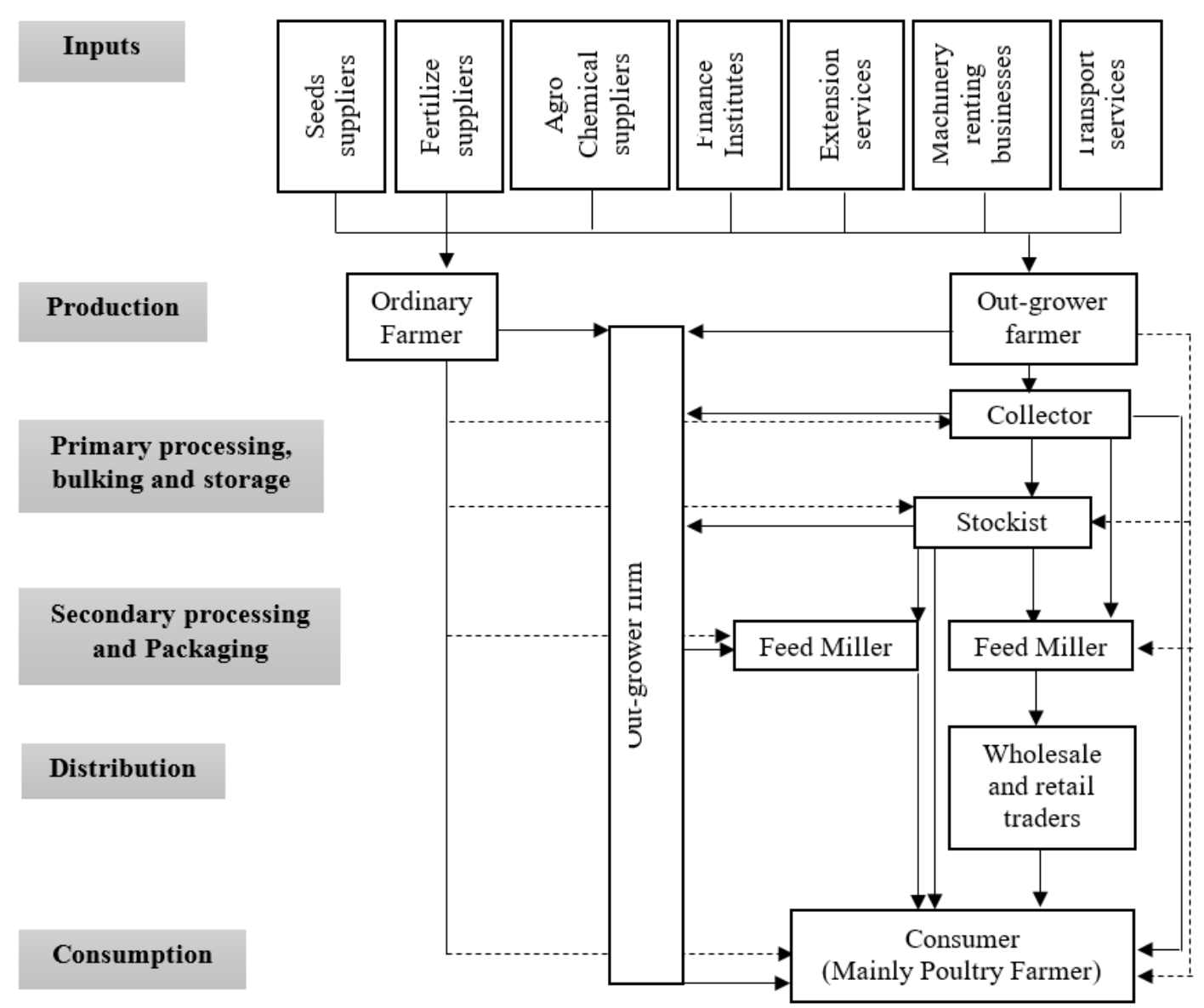

Figure 01: Maize value chain within the key maize growing areas in Sri Lanka 


\section{Primary production of maize for animal feed:}

Rural maize farmers; OG farmers and ordinary farmers, are the major value chain participants in maize value chain. Results revealed that the average land holding of both the groups of farmers was 9 acres. However, the actual average land utilized for maize cultivation was 6.5 acres and 8 acres by OG farmers and ordinary farmers respectively. The key reason for the poor land utilization for maize by $\mathrm{OG}$ farmers was their extremely poor control over the final price for their harvest under the $O G$ cultivation system. In contrary, ordinary farmers exercised a better bargaining power hence higher land utilization for maize cultivation. Farmers acquire the necessary inputs and obtain the services of production from input suppliers and service providers for farming. They have utilized their own savings and/or credit from credit providers, credit input suppliers or engage in out grower operations to acquire necessary inputs of production.

Under OG farming system, OG farmers and OG firms enter into a signed agreement where the OG firm agreed to buy-back the harvest at the right quality range at the agreed price-range and farmers to supply their entire harvest from OG farming operation only to the OG firm. Further, OG farmers were facilitated by a bank to obtain credit up to $30,000.00 \mathrm{LKR}$ per acre which was channeled to the OG firm to provide on-time supply of basic inputs: hybrid seeds, crop protection chemicals and fertilizer along with agricultural extension services throughout the season and the insurance company for an insurance premium. A similar type of $O G$ farming arrangement was explained by Esham, et al., (2005) with regard to the hybrid maize farming in Monaragala district, Sri Lanka.

Out-grower firms provide high quality maize for the animal feed; mainly poultry industry by sourcing the material through OG operations. According to the discussions with the key informants, a good demand was obtained through the production of maize that is free from fungi contaminations, that has low debris, and a moisture content ranging from 14per cent (the best level) to 27 per cent. Also, harvesting has to be done at the right time of maturity and fullness of seeds for a superior produce.

Results revealed that the labour, machinery rental and the total input cost are the major cost components of the cost of production of maize (Table 02). Farmer's ability to earn a considerable profit from per kilo of maize was further reduced by high costs of dehulling, packing, transport and handing. Results showed that the transport cost was 3.00 LKR per kilo and the packing cost was 60 cents per kilo for $50 \mathrm{~kg}$ packaging bags.

Maize farmers enjoyed a very restricted bargaining power on sales price which was a key reason to enter into OG farming (Chavas and Holt, 1996:Barrett et al., 2012). This also encouraged the $\mathrm{OG}$ farmers to engage in side-sales ${ }^{1}$ leading to high transaction and coordination costs for the OG firms (Delpierre, 2009: Miyata et al., 2009). Their side-sales network was composed of collectors, stockists, feed millers and poultry farmers (indicated with dotted lines in Figure 01). Being lack of their own transport, maize farmers were enthusiastic in reaching profitable markets by selling to buyers who visit their farmlands. There was a strong communication network among farmers which enabled them to approach a buyer who offered a high price. Additionally, they have had extra income sources; 64 percent of them cultivated other field crops such as cereals, pumpkin, watermelon, sesame and cucumber to earn an income of LKR 47,880 per season and another 11 percent were engaged in offfarm business activities that brought an income of LKR 36,750.00 per month. According to the farmers and key informants, their farming activities were highly affected by environmental factors such as rainfall, post-harvest factors such as humidity and non-environmental factors such as transport cost, distance to $\mathrm{OG}$ firm, and the time and labour for cost of sales. Farmers sell their produce in two forms, wet maize and dry maize. Sale of wet maize was to minimize the time between harvesting and sales to reduce immediate post-harvest losses such as fungal infections and pest attacks such as birds and elephants. This reduced the cost of production (COP) as well. Production and sales of dry maize was to earn a comparatively a high income through a better product quality. 
Table 02: $\quad$ Production cost variables (per Acre)

\begin{tabular}{llcc}
\hline & \multicolumn{1}{c}{ Activity } & LKR & \% from total \\
\hline 1 & Total input cost & 10,670 & 29.5 \\
2 & Labour cost & 12,000 & 33.2 \\
3 & Machinery rental cost & 9,500 & 26.3 \\
4 & Dehulling and packing cost & 2,500 & 7.0 \\
5 & Transporting and handling cost & 1,500 & 4.0 \\
& $\quad$ Total cost & 36,170 & 100.0 \\
\hline
\end{tabular}

3. Bulking by collectors and stockists: Results showed that the bulking involved buying, storage, selling and transporting of maize from the farmlands to feed manufacturers by collectors, small to large scale stockists, small to large scale feed millers and poultry farmers. Out-grower firms were involved in all these value chain activities. In addition, OG firms have employed Agriculture Extension Officers (AEOs) for checking of field moisture level, valuation, weighing and generating the field records of the harvest. The results showed that the farmer decided where to sell the harvest based on the valuation by the AEO.

Collectors: At the upper end of MVC, collectors' involvement has become high. They directly procured maize from farmers (five to ten farmers per collector per season) and payments were made only after the collector has sold the bulk retaining a profit of approximately 3.00 to 4.00 LKR per kilo for themselves. Their lack of storage facilities made them to conclude immediate sales to the next buyer without drying. Pricing was done under two categories; wet price and dry price while checking with their experience (by chewing). The sales network of collectors was comprised with stockists, feed millers and consumers (mainly poultry farmers) and continued business activities with same customer group through mutual connections and mobile communication.

Stockists: Maintaining storage (of 100mt to $500 \mathrm{mt}$ as small scale and up to $32,000 \mathrm{mt}$ as large scale) and $\mathrm{OG}$ operations (OG farmer bases of up to 500 farmers as small scale (SS); above 500 and up to 15,000 farmers as large scale (LS)) were the two main activities of stockists. The SS stockists are mainly the local dealers and boutique keepers who have invested their incomes on OG operations. Other than for farming, they have provided micro credit for household requirements of farmers and tide a group of farmers for an ensured seasonal supply. Only six percent of them allowed a cash settlement and others buy-back the harvest as a credit settlement. Record keeping is prominent among stockists and only 13 percent maintains a signed contractual agreement with their credit farmer base. Stockists received 1,300 kg per acre per season of maize (6 percent of them procure dry maize only). The supplier network was developed via mobile communication and mutual relationships. Seventy-three percent of stockists have their own vehicles and 80 per cent of them have hired labour for seasonal operations (four to six units of labour per day at a daily wage of $1,000.00$ LKR during the season).

The optimum moisture content of maize should be 14 per cent for stock keeping. For that, SS stockists practiced conventional sun drying (at threshing fields or at roadsides) or low technology dryers, and sold to SS feed millers (mainly in Colombo and Kuliyapitita) and LS feed millers or for the LS buying firms especially (67 per cent of stockists) during the off season (June-September) at a higher price. Only a very few LS stockists were engaged in MVC as OG firms. They have a well-planned procurement procedure with competitive prices, transport services, processing units with high technology and storage units for successive business operations and sold their bulk to feed manufacturers. However, their vertical coordination in MVC and business operations were exposed to high risk due to imports of maize and crop failures. 
4. Secondary processing and packaging: Maize is used as the main ingredient in the formulation of poultry rations (nearly 60 percent out of the ration formulas). The feed processing stage of the MVC was mainly handled by the LS private sector feed millers and also SS feed millers and poultry farmers. In general, few large-scale poultry farms operate their own feed mills and occupy 50 percent of the national animal feed production.

5. Distribution: Provender products and/ or processed maize were distributed to final consumer primarily in bulk packages $(50 \mathrm{~kg})$. The distribution involved both direct supplies and retail chains including whole sellers and retailers.

6. Consumption: Small-scale to large-scale poultry producers are the key final consumers of the MVC.

\section{Value chain of the out-grower firm}

Supply flow: The OG firms have their own OG farmer base to have an assured supply for their stock. However, OG firms do not depend only on their OG farmer base, but also the supply from ordinary farmers and middlemen (collectors and stockists). Out-grower firms have targeted their supplies in the proportions of 55 percent from OG farmers' supply, 19 percent from ordinary farmers' supply and 26 percent from middlemen's supply. However, the OG firms failed to cover their targeted supply as planned and most of the target was covered through the supply from ordinary farmers and middlemen which respectively accounted to 40 per cent and 35 percent of total supply of maize received. Only 25 percent of their requirement came from their OG farmers. Therefore, at the end of the season, a significant deviation showed in OG farmers' supply than the expected volume. Discussions with farmers and key informants revealed that the farmers used to take credit (for household and farming purposes) from various sources including collectors and stockists and were bound to sell to these middlemen who made the OG farmers price-takers. Therefore, OG firms were unable to purchase the whole harvest of OG farmers despite their support by the way of seeds and inputs. This had an impact on the profitability of the OG firms as they bought stocks from middlemen at higher prices.

Price flow mapping: Several factors were responsible for the buying price of raw maize. The main factor was the moisture content of the seeds. Maize is graded from dry to wet based on the moisture content, i.e. from 14 to 27 percent. Price was increased with every reducing one percent of moisture content. Other factors determining the buying price were purchasing period within the season, competitor pricing, import price of maize and the quantity incentives. According to the results, the same price range was provided for all the suppliers by the OG firm. This introduced a free-rider behaviour by the $\mathrm{OG}$ farmers as they were provided with all the support by the OG firm during the cultivation of the crop. A quantity incentive scheme of Cents 50 for each kilo of over 50,000MT of supply and Rs. 1.00 for over $100,000 \mathrm{MT}$ of supply were paid by the OG firms to motivate the suppliers. Supply from middlemen; collectors and stockists, were higher than the target due to the above incentive given for a bulk supply.

Value addition process: The direct value additions occurred when the product passes through the direct value adding links in the chain while, indirect value additions and nonvalue additions occur at the indirect non-value adding links. Even their presence in the value chain caused price increments. They cannot be excluded as their presence is necessary for the production flow at the up-stream nodes. Following value chain map explain the value chain actors' participation in different levels of the maize value chain (Figure 02).

Drying was the main value adding activity in MVC. Conventional sun drying was mainly practiced by farmers and middlemen. Majority of them had the lack of proper space for sun drying and therefore, used threshing lands, road side, house premises and rock surfaces. Some stockists used low technology dryers. Because of these practices, deterioration of quality of the final product occurred due to discoloration and addition of foreign materials such as stones etc. 


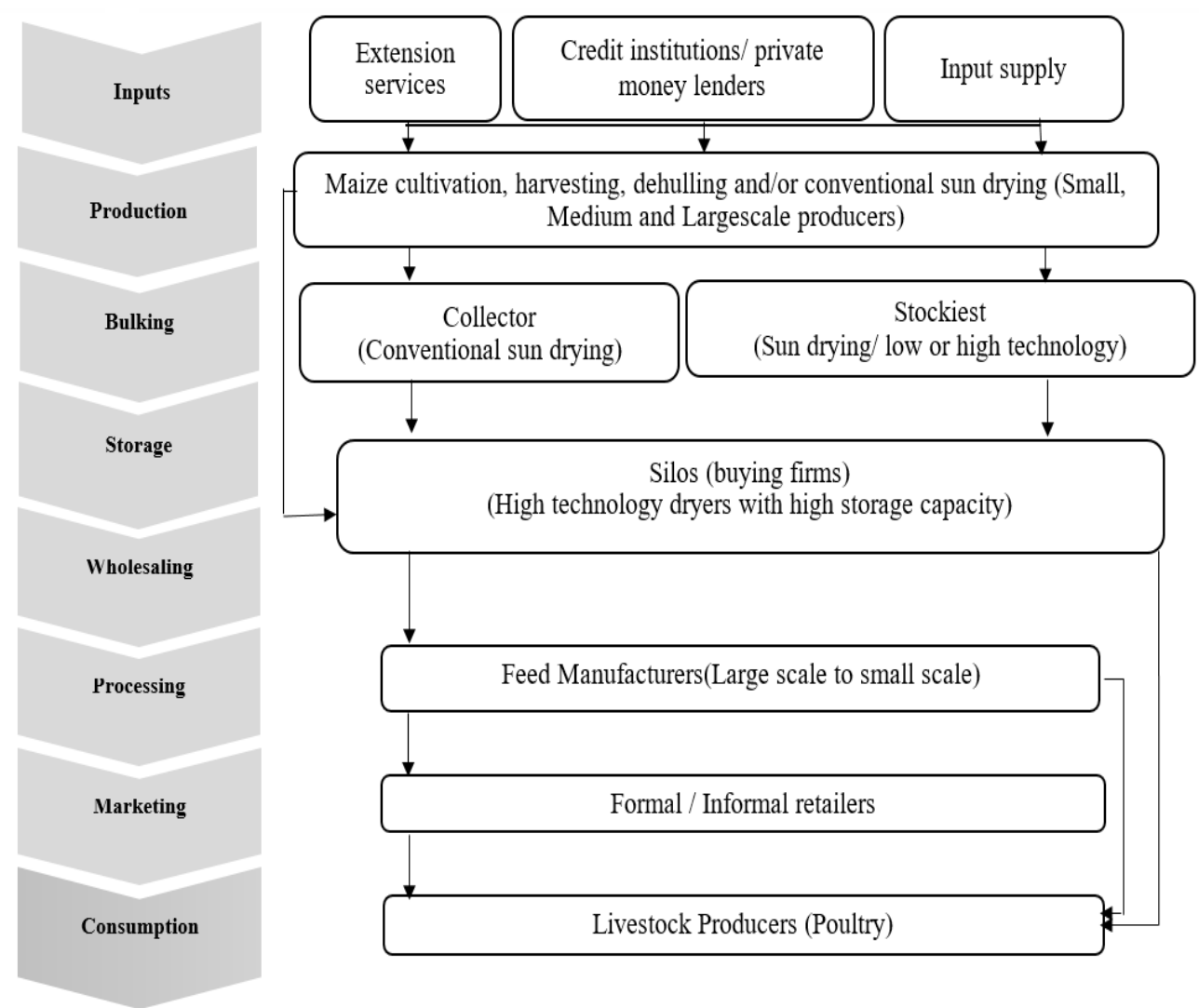

Figure 02: Value addition in maize value chain

De-hulling was the second main value-added activity done by farmers. Bulk packing by the middlemen which simultaneously added a cost, caused a reduction in price of maize at the farm-gate. Some of the reasons for this were the poor bargaining power of individual farmers, various assistance transporting the harvest at a nominal charge which was deducted when the final payment was made to the farmers, offered by the middlemen to the farmers ${ }^{2}$, and middlemen's need to offset the quantity loss at their end. Therefore, direct sales between farmers and OG firm enabled to obtain good profits for both parties.

Activities involved through the maize supply chain were categorized as value adding activities; non-cost incurring non-value adding activities; and cost incurring non-value adding activities. Direct value adding activities at farmer level included harvesting maize from the field, dehulling to produce semi processed maize and drying. Well-dried maize had a premium price in the market. Drying reduced the moisture and enhanced the quality by reducing fungi contamination and odor formation. According to key informants, this resulted a longer storage life for maize seeds. However, when the product goes through lengthier value chains, repetition of non-cost incurring non-value adding activities such as; moisture checking, weighing, and quality checking for fungi contaminations and discoloration, and cost incurring non-value adding activities such as; loading, unloading, and transport led to extra costs for value chain members causing a reduction of their profits. The existence of mechanisms already adapted in MVC have created several limitations such as most of the time transportation of maize was handled by middlemen at their own village because farmers have no vehicles to transport the harvest and delays of the OG firm's transport vehicles, and even quality deteriorated by extending the storage period especially in wet maize, for farmers to engage in direct sales with the buying firms for spot sales. This has increased the involvement of middlemen (Kirimi, et al., 2011). Total number of times that the product was handled are given in the Table 03 . 
Table 03: $\quad$ Count of value chain activities in all the stages of wet and dry maize value chains

\begin{tabular}{lcccc}
\hline & $\begin{array}{c}\text { Number of value- } \\
\text { adding activities }\end{array}$ & $\begin{array}{c}\text { Number of non-cost } \\
\text { incurring non-value } \\
\text { adding activities }\end{array}$ & $\begin{array}{c}\text { Number of cost } \\
\text { incurring non-vale } \\
\text { adding activities }\end{array}$ & $\begin{array}{c}\text { Total number of } \\
\text { value chain activities }\end{array}$ \\
\hline Dry MVC & 11 & 8 & 14 & 33 \\
Wet MVC & 4 & 9 & 11 & 24 \\
\hline
\end{tabular}

\section{Out-grower farmer loyalty}

The FLI was computed based on OG farmers' opinion on the indicators included in the Table 01 . The index value ${ }^{3}$ may range from 0 to 1 . The actual FLI within the sample of OG farmers ranged between 0.5733 and 0.9067 with a mean of 0.76 .The $\mathrm{OG}$ farmers were classified into four groups based on their actual FLI for detailed analysis using Delinius Hodges (1959) cumulative method adapted by Senthilkumar et al., (2009). The range of actual values between maximum and minimum FLI (0.9067 and 0.5733 respectively) found in the field were divided into four categories as very high loyalty $(0.9067-0.8234)$, high loyalty $(0.8235$ $-0.7410)$, moderate loyalty $(0.7400-0.6556)$ and low level of loyalty (0.6555 - 0.5733) (Figure 03). It was found-out that 30 and 37 percent of OG farmers were in the categories of very high and high levels of loyalty respectively. The results suggested that OG farming seemed a good strategy that may be developed through farmer loyalty.

According to the opinions of $\mathrm{OG}$ farmers, even they have a good healthy relationship (mean $=0.609$ ) with their OG firm which was built through the firm's extension team, OG farmers' satisfaction (mean $=0.5407$ ) and trust towards the OG firm (mean=0.5317) was moderate. This was due to their satisfaction on the buying price of OG firm (mean=0.4462) and income after loan and sales charges (mainly handling and transport) deducted (mean $=0.3341$ ) were considerably low. And their trust of ability to gain a higher price for their produce (mean $=0.3341$ ) and obtain better profits from OG farming (mean $=0.4000$ ) also, become doubtful and reduce their trust towards the OG firm. Therefore, OG farmers engaged in side-sales with buyers who offered a higher price than the OG firm, even though their initial services were valued by the OG farmers. The situation was further explained under their loyal commitment (Figure 04); nearly two thirds of OG farmers $(77 \%)$ were reluctant to sell their whole harvest to OG firm because of low price compared to ad hoc buyers/ collectors. However, OG farmers had a healthy opinion to re-enter into $\mathrm{OG}$ operations and also to convince other farmers to engage in OG operations. This was due to following opinions of OG farmers. First, they were satisfied about the quality of inputs provided on time; service provided during procurement; and the assured buy-back. Secondly, they had a healthy relationship with the OG firm due to the ability of contacting Agricultural Extension Officer (AEO) of the firm any time; availability of on-call AEO; firm's accountability; receiving instant solutions and farming issues; and firm's high service quality during buy-back operations. Thirdly, OG farmers trusted the firms of their high quality of inputs and services; increased quantity and quality of produce; high quality of extension service; and better service during buy back operations. These conflicts of interests made the OG programs ineffective especially in the long run of business operations of agribusinesses firms.

According to the responses of OG farmers, their loyal commitment on OG farming at the initial stage to enter and re-enter into OG operations (43 percent- highly agreed, 34 percent- agreed) and to provide word of mouth promotions (30 percent- highly agreed, 43 percent- agreed) was higher than their intentions at the end of the OG farming agreement. Spearmen's Rank Correlation test results indicated that OG farmer consideration on selling their production for their OG firm does have a positive correlation with the OG firm's price offer. The results were significant at 0.002 with 0.327 correlation coefficient value $(\alpha=0.001$ and $\mathrm{N}=67)$. 


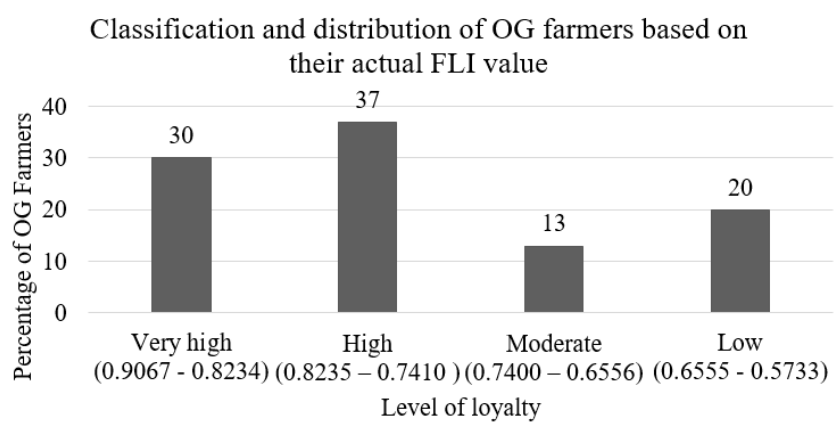

Figure 03: Classification and distribution of OG farmers based on their actual FLI value

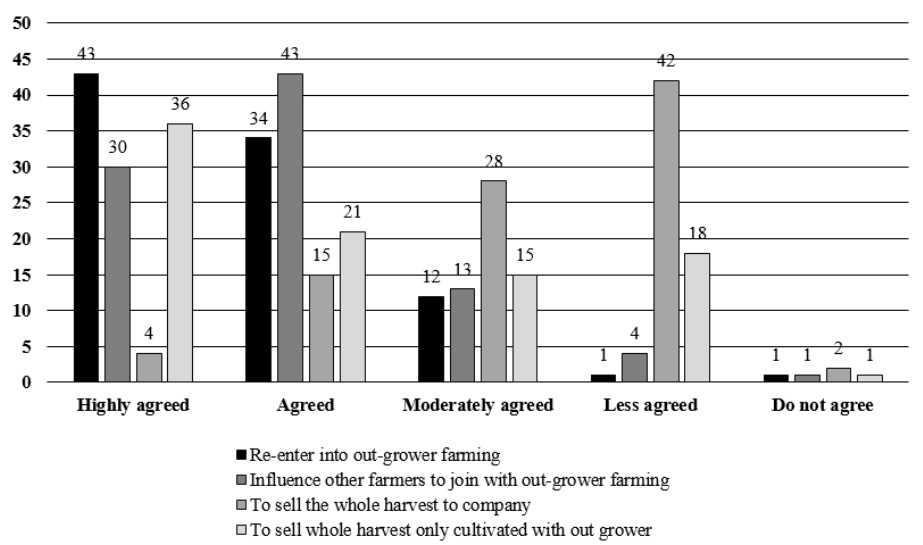

Figure 04: Loyal commitment of out-grower farmers about the out-grower farming

According to the test results, there was a significant relationship $(p=0.002)$ between farmer satisfaction on OG firm's buying price on farmer decision whether or not to sell their total produce to OG firm. Several studies had revealed that farmers are more favored towards a fixed price than varying prices (Minten et al., 2009: Miyata et al., 2009: Tripathi et al., 2005). Therefore, the company pricing had a (weak) positive effect on out-grower farmer decision on selling their total harvest to the OG firm. OG farmers were dissatisfied about the price; low final income; and their reluctance to bare the transport and handling costs. This dissatisfaction led 77 percent of OG farmers not to sell their whole OG harvest to the firm (33 percent of OG farmers-sold their entire harvest; 16 percent - sold more than half of their total harvest, 1 percent - sold less than half of their harvest and 50 percent did not sell any proportion from their harvest) (Figure 05), but to other parties such as collectors and stockists to escape from repaying the bank loan and the price for inputs obtained for OG farming (Barrett et al., 2012). Therefore, it was also established that the OG farmer's consideration on short term benefits compared to the long-term benefits was high. As a result, the situation created the OG operations practically a less effective strategy.

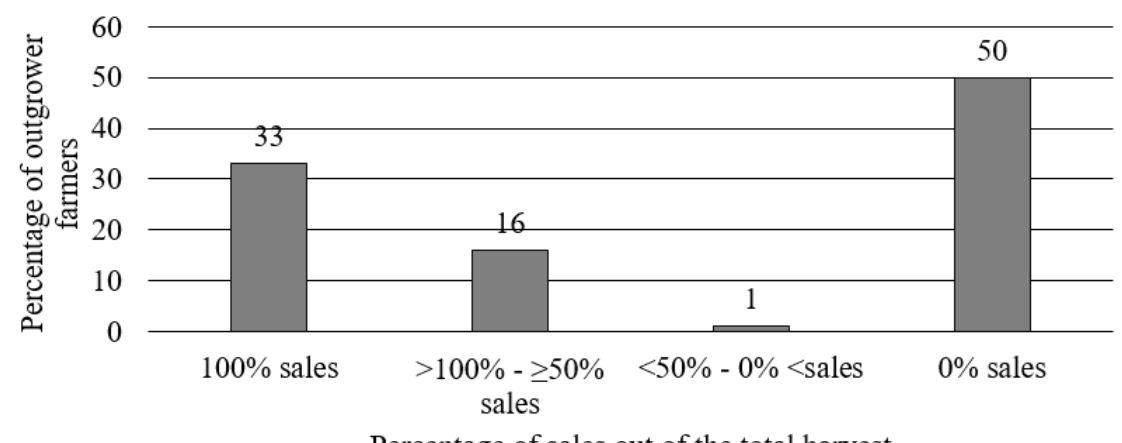

Percentage of sales out of the total harvest

Figure 05: Sales percentage out of total harvest from out-grower farming 


\section{CONCLUSIONS}

The study assessed the engagements at the upstream maize value chain including; the key participants and their various activities, and the role of out-grower firm while assessing the effectiveness of adapting out-grower farming as a business strategy for an assured supply besides competitive price offers. The results showed that, the key value adding participants were the maize farmers, out-grower farmers and ordinary farmers, stockists, feed millers and the poultry farmers. Collectors, wholesale and retail traders were also part of the maize value chain as nonvalue adding players. Apart from them, inputs and service providers who provided necessary variables of production: labour, inputs, finance, machinery renting and transport services, were also involved in the MVC.

Out-grower farmers were supported with a bank loan and a crop insurance scheme within the out-grower farming. They utilized lesser land extent (6.5 acres) compared to ordinary farmers ( 8 acres) where they both had an equal land holding power. They had poor bargaining power over the price. Both farmer categories produced two types of maize; wet and dry (moisture content ranged from 14 to 28 percent) where wet maize was to reduce the immediate post-harvest losses and cost of production, and dry maize was to earn a better income (the price was increased for 1 percentage each reducing moisture reading) from quality produce. The out-grower firms have covered their targeted supply mostly from middlemen ( 40 per cent) and ordinary farmers (35 per cent), other than the out-grower farmers ( 25 per cent) because outgrower farmers were more inclined to engage in side-sales as they were poor in bargaining for the price. The situation was unprofitable for out-grower firms as they had to buy the deficit from the middlemen at a higher price.
The results of Farmer Loyalty Index revealed that, 30 percent and 37 percent of out-grower farmers belonged to very high level and high level of loyalty respectively suggesting that the out-grower farming is a good strategy for agribusiness firms. Apparently, among the sub-dimensions the satisfaction about the buying price of out-grower firm; and income after deduction of bank loan, other recoveries, handling and transport charges; were considerably low. Their hope on the ability to gain a higher price for their produce and to obtain better profits from out-grower farming have become doubtful and caused to induce their free-rider behavior. However, 77 percent of out-grower farmers had not sold their total harvest to the out-grower firm. This situation was further explained through Spearman's Rank Correlation test results where, outgrower farmers had more consideration about the buying price (at 0.002 of significant level) other than the advantages they gained from the out-grower farming to sell their total harvest to the out-grower firm. Results concluded that the out-grower farming is a good strategy but showed failures during the harvesting season, out-grower firms had to address the out-grower farmers' dissatisfaction about the out-grower firm's pricing and the final income to increase the success rate of out-grower farming.

\section{End Notes}

1.Selling the produce to parties other than the $\mathrm{OG}$ firm.

2.These include financial assistance for household and cultivation uses, and material assistance such as the provision of inputs. The results revealed that the contracted farmers of OG firms showed a dependency towards middlemen despite their OG contracts with their OG firms.

3.Reliability of the variables of FLI (Cronbach's alpha) $=0.825$

\section{REFERENCES}

Abebe, G.K., Bijman, J., Kemp, R., Omta, O. and Tsegaye, A., (2013). Contract farming configuration: Smallholders' preferences for contract design attributes. Food Policy, Vol.40, pp.14-24. 
Andreassen, T.W. and Lindestad, B., (1998). The effect of corporate image in the formation of customer loyalty. Journal of Service Research, Vol. 1(1), pp. 8292.

Athaide, G.A., Meyers, P.W. and Wilemon, D.L., (1996). Seller-buyer interactions during the commercialization of technological process innovations. Journal of Product Innovation Management: an international publication of the product development \& management association, Vol. 13(5), pp. 406-421.

Barrett, C.B., Bachke, M.E., Bellemare, M.F., Michelson, H.C., Narayanan, S., Walker, T.F., (2012). Smallholder participation in contract farming: comparative evidence from five countries. World Development Vol.40, pp.715-730.

Batt, P.J. and Rexha, N. (2000). Building trust in agribusiness supply chains: a conceptual model of buyer-seller relationships in the seed potato industry in Asia. Journal of International Food \& Agribusiness Marketing, Vol. 11(1), pp. 1-17

Batt, P.J., (2003). Building trust between growers and market agents. Supply Chain Management; An International Journal, Vol. 8(1), pp. 65-78.

Bellemare, M.F., (2010). Agricultural extension and imperfect supervision in contract farming: evidence from Madagascar. Agricultural Economics Vol.41, pp.507-517.

Bellemare, M.F., (2012). As you sow, so shall you reap: the welfare impacts of contract farming. World Development Vol.40, pp.1418-1434.

Bennett, R. and Rundle-Thiele, S., (2002). A comparison of attitudinal loyalty measurement approaches. Journal of Brand Management, Vol. 9(3), pp. 193-209.

Bettencourt, L.A. and Brown, S.W., (1997). Contact employees: Relationships among workplace fairness, job satisfaction and prosocial service behaviors. Journal of retailing, Vol. 73(1), pp. 39-61.

Bijman, J., (2008). Contract Farming in Developing Countries: an Overview. Working Paper, Wageningen University, The Netherlands, May 2008.

Boehlje, M. and Doering, O. C., (2000). Farm policy in an industrialized agriculture. Journal of Agribusiness (Special Issue), Vol. 18(1), pp. 53-60.

Bogetoft, P., Olesen, H.B., (2002). Ten rules of thumb in contract design: lessons from Danish agriculture. European Review of Agricultural Economics Vol.29, pp.185-204.

Boniface, B., Gyau, A., Stringer, R. and Umberger, W., (2010). Building producer loyalty in Malaysia's fresh milk supply chain. Australasian Agribusiness Review, Vol. 18(5), pp. 66-84.

Central Bank of Sri Lanka, (2014-2018). Annual report [Online]Available [https://www.cbsl.gov.lk/ sites/default/files/cbslweb_documents/publications/annual_report/year/en/6_Chapter_02. pdf] Accessed [15.07.2019 at 10.50 - 11.50 a.m.]

Champika, P.J. and Abeywickrama, L.M., (2014). An evaluation of maize contract farming system in Sri Lanka: adoption, problems and future prospects. Tropical Agricultural Research, Vol. 26(1), pp. 62-73. 
Chaudhuri, A. and Holbrook, M.B., (2001). The chain of effects from brand trust and brand affect to brand performance: the role of brand loyalty. Journal of marketing, Vol. 65(2), pp. 81-93.

Chavas, J.P. and Holt, M.T., (1996). Economic behavior under uncertainty: A joint analysis of risk preferences and technology. The review of economics and statistics, Vol. 78(2), pp.329-335.

Chumpitaz, C.R. and Paparoidamis, N.G., (2007). Service quality, relationship satisfaction, trust, commitment and business-to-business loyalty. European journal of marketing, Vol.41 (7/8), pp. 836-867.

Dalenius, T. and Hodges Jr, J.L. (1959), Minimum variance stratification, Journal of the American Statistical Association, Vol. 54(285), pp. 88-101.

De Wulf, K., Odekerken-Schröder, G. and Iacobucci, D., (2001). Investments in consumer relationships: a cross-country and cross-industry exploration. Journal of marketing, Vol. 65(4), pp. 33-50.

Delpierre, M., (2009). Farm input use in a context of liquidity constraints and contract unenforceability. Journal of African Economies, Vol. 18, pp. 496-528.

Department of Agriculture Sri Lanka (DOASL), (2001). Maize; nutritive value, verities, variety management and cultivation. Field crop development and research institute.

Department of Agriculture Sri Lanka Lanka (DOASL), (2018). Crop forecast 2018/2019. Socioeconomic and planning Centre, Department of Agriculture, Peradeniya, Sri Lanka.

Department of Animal Health and Production (DOAP\&H), (2016). Poultry Industry; production, imports, exports and per-capita consumption, Key Statistics 2008-2017.

Eaton, C., and Shepherd, A.W., (2001). Contract Farming: Partnership for Growth. FAO Agricultural Services Bulletin 145. Food and Agriculture Organization, Rome, Italy.

Esham, M. and Usami, K., (2005). Present state and issues of farmers-agribusiness linkages through farmer organization/group in Sri Lanka: A case study of hybrid maize. Journal of Agricultural Development Studies (Japan).

Esham, M., Usami, K., Kobayashi, H. and Matsumura, I., (2005). Determinants of Farmers' Participation in Farmers-Agribusiness Linkage and Its Implication for Income Distribution in Sri Lanka. Journal of Rural Problems, Vol. 41(1), pp.200-205.

Esham, M., Usami, K., Kobayashi, H. and Matsumura, I., (2006). An economic study of contract farming in the fruit and vegetable industry in Sri Lanka: A case study of gherkin (Cucumis sativus) production. Journal of Rural Problems, Vol. 42(1), pp.14-23.

Fornell, C., Johnson, M.D., Anderson, E.W., Cha, J. and Bryant, B.E., (1996). The American customer satisfaction index: nature, purpose, and findings. The Journal of Marketing, pp. 7-18.

Fulton, A.L. and Vlark, R.J., (1996). Farmer decision making under contract farming in northern Tasmania.

Glover, D.J., (1984). Contract farming and smallholder OG schemes in less-developed countries. World development, Vol.12(11-12), pp. 1143-1157. 
Goodwin, B.K. and Schroeder, T.C., (1994). Human capital, producer education programs, and the adoption of forward-pricing methods. American Journal of Agricultural Economics, Vol. 76(4), pp. 936-947.

Gow, H.R., Streeter, D.H. and Swinnen, J.F.M., (2000). How private contract enforcement mechanisms can succeed where public institutions fail: the case of Juhocukor a.s. Agricultural Economics Vol., 23, pp. 253-265.

Grosh, B., (1994). Contract farming in Africa: an application of the new institutional economics. Journal of African Economies Vol. 3 pp. 231-261.

Guo, H., Jolly, R.W., Zhu, J., (2005). Contract farming in China: Supply chain or ball and chain? In: Paper Presented at 15th Annual World Food and Agribusiness Symposium. IAMA, Chicago, June.

Gyau, A. and Spiller, A., (2007). The role of organizational culture in modeling buyer-seller relationships in the fresh fruit and vegetable trade between Ghana and Europe. African Journal of Business Management, Vol. 1(8), pp. 218-229.

Herath, D., Weersink, A., (2009). From plantations to smallholder production: the role of policy in the reorganization of the Sri Lankan tea sector. World Development Vol.37, pp.1759-1772.

Hines, P. and Rich, N., (1997). The seven value stream mapping tools. International journal of operations \& production management, Vol. 17(1), pp. 46-64.

Hueth, B., Ligon, E., (1999). Producer price risk and quality measurement. American Journal of Agricultural Economics, Vol.81, pp.512-524.

Jacoby, J. and Chestnut, R.W., (1978). Brand loyalty: Measurement and management. Journal of advertising, Vol.8(2) pp. 46.

Kaplinsky, R. and Morris, M., (2000). A handbook for value chain research, Vol. 113. University of Sussex, Institute of Development Studies.

Karim, R. and Biswas, J., (2016). Value stream analysis of vegetable supply chain in Bangladesh: a case study. International Journal of Managing Value and Supply Chains, Vol. 7(2), pp. 41-61.

Karunagoda, K.S., Karunagoda, K.P.N.S. Gunawardhane, H.P. Senanayake, S.P.R.P. and Wickramasinghe, Y.M., (2010). Factors affecting the adoption of agricultural forward sales contracts in Sri Lanka. Journal of multidisciplinary studies. Vol.1(1), pp. 17-24.

Key, N. and Runsten, D., (1999). Contract farming, smallholders, and rural development in Latin America: the organization of agro-processing firms and the scale of OG production. World development, Vol. 27(2), pp. 381-401.

Kirimi, L., Sitko, N., Jayne, T.S., Karin, F., Muyanga, M., Sheahan, M., Flock, J. and Bor, G., (2011). A farm gate-to-consumer value chain analysis of Kenya's maize marketing System. Working paper No. 111, pp. 1-75. Tegemeo Institute of Agricultural Policy and Development.

Kirsten, J. and Sartorius, K. (2002). Linking agribusiness and small-scale farmers in developing countries: is there a new role for contract farming? Development Southern Africa, Vol. 19(4), pp. 503-529. 
Minten, B., Randrianarison, L. and Swinnen, J.F.M., (2009). Global retail chains and poor farmers: evidence from Madagascar. World Development Vol. 37, pp.1728-1741.

Miyata, S., Minot, N. and Hu, D., (2009). Impact of contract farming on income: linking small farmers, packers, and supermarkets in China. World Development Vol.37, pp.1781-1790.

Morfi, C., Ollila, P., Nilsson, J., Surry, Y., Feng, L. and Karantininis, K., (2014). The switching behaviour of Finnish co-operative members in relation to their commitment and loyalty (No. 182774).

Natesan, S. and Jogaratnum, T., (1997). Maize production in Sri Lanka. Agro Enterprises Development Project, Colombo, Sri Lanka, Report Vol. 57, pp. 1-57.

Nilsson, J., Svendsen, G.L. and Svendsen, G.T., (2012). Are large and complex agricultural cooperatives losing their social capital?. Agribusiness, Vol. 28(2), pp. 187-204.

Oliver, R.L. (1999). Whence consumer loyalty? The Journal of Marketing, Vol.63(4) pp. 33-44.

Oya, C., (2012). Contract farming in Sub-Saharan Africa: a survey of approaches, debates and issues. Journal of Agrarian Change Vol.12, pp.1-33.

Prahinski, C. and Benton, W.C., (2004). Supplier evaluations: communication strategies to improve supplier performance. Journal of Operations Management, Vol. 22, pp. 39-62.

Prowse, M., (2012). Contract farming in developing countries: a review. Institute of Development Policy and Management, University of Antwerp.

Ramsay, J. and Wagner, B.A., (2009). Organisational Supplying Behaviour: Understanding supplier needs, wants and preferences. Journal of purchasing and supply management, Vol. 15(2), pp. 127-138.

Rauyruen, P. and Miller, K.E., (2007). Relationship quality as a predictor of B2B customer loyalty. Journal of business research, Vol. 60(1), pp. 21-31.

Reardon, T and Barrett, C.B., (2000). Agro-industrialization, globalization and international development: an overview of issues, patterns and determinants. Agricultural Economics (Special Issue), Vol. 23, pp. 195-205.

Reardon, T., Barrett, C.B., Berdegué, J.A., Swinnen, J.F.M., (2009). Agrifood industry transformation and small farmers in developing countries. World Development, Vol.37, pp.1717-1727.

Reichheld, F.F., (1993). Loyalty-based management. Harvard business review, Vol. 71(2), pp. 6473.

Rosairo, H.R. and Potts, D.J., (2016). A study on entrepreneurial attitudes of upcountry vegetable farmers in Sri Lanka. Journal of Agribusiness in Developing and Emerging Economies, Vol. 6(1), pp. 39-58.

Senanayake, M.S., (2004). What is ailing farmer companies in their transformation into successful business entities. Third International Conference of the Japan Economic Policy Association. 
Senthilkumar, R., Khandekar, N. and Narmatha, N., (2009). Knowledge level among poultry entrepreneurs on scientific layer farming. Tamilnadu Journal of Veterinary and Animal Sciences, Vol.5 (3), pp. 94-98.

Singh, S., (2002). Contracting out solutions: political economy of contract farming in the Indian Punjab. World Development, Vol.30, pp.1621-1638.

Smale, M., Just, R.E., Leathers, H.D., (1994). Land allocation in HYV adoption models: an investigation of alternative explanations. American Journal of Agricultural Economics, Vol.76, pp. 535-546.

Sofranko, A., Frerichs, R., Samy, M. and Swanson, B., 2000. Will farmers organize: Structural change and loss of control over production. Illinois Specialty Farm Products, University of Illinois. Research Paper.

Stevenson, G.W. and Pirog, R., (2008). Values-based supply chains: Strategies for agrifood enterprises of the middle. Food and the mid-level farm: Renewing an agriculture of the middle, MIT press, pp. 119-143.

Tripathi, R.S., Singh, R. and Singh, S., 2005. Contract farming in potato production: an alternative for managing risk and uncertainty. Agricultural Economics Research Review, Vol. 18(3472016-16722), pp.47-60.

Tsay, C.Y., Li, Y.J. and Lin, Y.S., (2014). A Study of the Policy-oriented Special Agricultural Loan on Customer Satisfaction and Loyalty of Farmers' Association in Hualian County, Vol(1) pp. 1-57.

Warning, M. and Key, N., (2002). The social performance and distributional consequences of contract farming: An equilibrium analysis of the Arachide de Bouche program in Senegal. World Development, Vol.30, pp.255-263.

Weatherspoon, D., Cacho, J. and Christy, R., (2001). Linking globalization, economic growth and poverty: impacts of agribusiness strategies on sub-Saharan Africa. American Journal of Agricultural Economics, Vol.83(3), pp. 722-729.

Zeithaml, V.A., Berry, L.L. and Parasuraman, A., (1996). The behavioral consequences of services quality. Journal of Marketing, Vol. 60(2), pp. 31-46. 